\title{
Experiences of going to court: witnesses with intellectual disabilities and their carers speak up
}

Tessy Beckene, Rachel Forrester-Jones and Glynis H Murphy

Tizard Centre, University of Kent

\section{Running head: Experiences of going to court}




\section{Abstract}

Background: People with intellectual disabilities are more vulnerable to sexual abuse and are more disadvantaged in the Criminal Justice System than the general population. However, little is known about the experiences of people with ID who have allegedly been victims of sexual abuse and also been witnesses in court.

Materials and Methods: This study used semi-structured interviews and a Grounded Theory approach to examine the experiences of 4 people with ID and 4 carers/supporters who had all attended trials.

Results: Findings showed that after the traumatic incident of abuse, a court experience could become a secondary source of trauma. Experience of this trauma was dependent on the quality and quantity of support people received and the understanding of intellectual disabilities amongst the legal participants. Conclusion: The findings argue for better training for legal participants who are in contact with vulnerable witnesses and better support structures for alleged victims. 


\section{Introduction}

As victims of crime, people with intellectual disabilities (ID) are more vulnerable to abuse of various types, mainly sexual abuse, than other care groups or the general population (Brown \& Stein, 1998; Jones, Bellis, Wood et al, 2012; Tharinger, Horton \& Millea, 1990). In society, people with ID may find themselves in a very powerless position, living in settings that make abuse more likely, easier to cover up and unlikely to be reported, with institutional settings tending to be particularly problematic (McCarthy \& Thompson, 1996; Murphy \& Clare, 2006). A lifelong dependency on caregivers can cause an overemphasis on compliance at the expense of developing independence, thus placing people with ID in situations of unusual and unquestioned trust, enhancing the possibility of coercion (McCarthy \& Thompson, 1996; Tharinger et al., 1990). For some people their disability can increase vulnerability: limited verbal skills can create situations in which coercion is not even necessary (Anderson, 1982) or can cause a barrier to preventing or reporting abuse. Most importantly, people with ID frequently lack sex education, including information about sexual abuse (Tharinger et al., 1990; Murphy \& O'Callaghan, 2004).

When someone with ID does disclose abuse, report rates to the police and the subsequent prosecution rates are thought to be lower than for the general population (McCarthy \& Thompson, 1997; Murphy 2016). Studies suggest that if victims of sexual abuse tell anyone about the crime, they tend to tell a family member or friends, and this is especially likely for people with ID, as they often 
have to rely on their carers to report to the police (Murphy, 2016). Nevertheless, a study in Cambridge suggested that $60 \%$ of the staff in residential day services would not report a major assault against a person with ID and $10 \%$ would not necessarily report a rape, if the perpetrator was another service user (Lyall et al., 1995). Several studies suggest diverse reasons for the low investigation and prosecution rates. For example, the police often have trouble identifying an ID (Sanders et al., 1997). In his interview study of 15 sergeants in the UK, Hellenbach (2011) found that only one person had an accurate understanding of ID. A focus group study in Australia suggested that police officers also often rely on physical appearance as an attribute of an ID (Douglas \& Cuskelly, 2012). This means that people with ID, especially those with a mild ID, are at risk of remaining unidentified, due to the lower likelihood of recognisable genetic disorders, their better adaptability, social competencies and absence of support staff (Hayes, 2007). In addition, when they are identified as someone with ID, the police may be reluctant to proceed with an 'unsafe witness' (Brown et al., 1995).

As a consequence of these kinds of difficulties, the influence of interviewing techniques (Clare \& Gudjonsson, 1993; Milne, Clare \& Bull, 1999; Kebbell, Hatton \& Johnson, 2004; van Nijnatten \& Heestermans, 2010) and the effect of ID on witness testimony (Murphy \& Clare, 2006) have been studied. Results suggested that people with ID have more difficulties relating to consent to sexual relationships, providing eye-witness accounts (Ericson \& Isaacs, 2003), and following court proceedings (Ericson \& Perlman, 2001; Kebbell, Hatton \& Johnson, 2004). Clare and Gudjonsson (1993) reported that in interviews, 
people with ID were more likely to acquiesce, to confabulate, to be compliant and suggestible than people without ID. However, interviewing techniques like the cognitive interview (Milne, Clare \& Bull, 1999), using free recall tasks, avoiding leading, false statement and suggestive questions (Perlman et al., 1994), could improve evidence from witnesses with ID and they could become perfectly good eye-witnesses.

Research has also suggested that people with ID were being examined in court in the same way as the general population, without any allowance for their ID (Kebbell, Hatton \& Johnson, 2004). People with ID's disadvantages in court make it easy for lawyers to make them appear unreliable in cross-examination. Kebell et al. (2004) compared transcripts of 16 trials in the UK involving people with ID to 16 transcripts of trials with people without ID and found that the questioning of both groups was almost identical. In cross-examination, barristers used high numbers of leading questions, yes/no questions, negative and multiple questions and repeated questions, which tend to enhance suggestibility. O'Kelly et al. (2003) compared the judicial interventions in 16 trials involving people with ID with 16 trials of the general population. They found no significant differences in the number of interventions made in both groups. These findings suggest that judges probably lack information about the vulnerabilities of people with ID.

After a campaign in England for better training for the police (VOICE UK, 1998) and calls to change the law, the Youth Justice \& Criminal Evidence Act 1999 was passed and started to come in force in 2001. Guidance for the implementation of 
the legislation was been published by the Home Office to help the police and the crown prosecution service to identify witnesses with ID early, and for interviewing and examining in order to get the best evidence from witnesses with ID (Home Office, 2000). The act allowed the use of special measures to enable vulnerable witnesses to give improved evidence in court (Cooke \& Davies, 2001). These include:

- The use of screens to protect the witness from being confronted by the accused.

- A live television link to the courtroom, through which the witness can give evidence at the actual time of the trial

- Exclusion of the public from the court in cases of sexual assault or intimidation

- Removal of wigs and gowns

- Video evidence-in-chief prior to the court case

- Video cross-examination prior to the court case

- Use of an intermediary, to assist the witness in understanding questions put to them and communicate answers to the court

Since the implementation of this act however, little research has been carried out to evaluate its usefulness for people with ID and little is known about individual's own views and opinions of that experience.

The aim of this paper is to report on an exploratory study of how people with ID who have allegedly been victims of sexual abuse, and their carers/supporters, experience the criminal justice process, from being interviewed by the police 
through to their appearance in court, and after the court case ends. To this end, the following research questions were addressed:

- How did participants experience disclosing to the police, going to court and being questioned by strangers about a very intimate subject and what impact did the whole process have on them?

- What influence did characteristics of the Criminal Justice System have on these experiences?

- How were people with ID supported before, during and after this process and how did they benefit from this support?

\section{Materials and Methods}

\section{Design}

In order to delineate the 'emic' or 'insider' understanding of witnesses with ID going to court, a small, in-depth, exploratory study design using qualitative methods (and semi-structured interviews) was used. A Grounded Theory approach (Glaser and Strauss 1967; Strauss \& Corbin, 1998) enabled the research process to begin inductively, exploring individual's experiences in court (including their thoughts and feelings), how the court process influenced their and their carers' experiences, and whether or not changes in the environment had an impact on their perception of the situation. Field notes made on initial interviews informed subsequent questions so that an in-depth discovery of the social phenomena could be captured. Grounded Theory is regarded as a particularly suitable approach for exploring topics that have been rarely studied (Goulding, 2002) and where it is the intention of the study to move beyond a 
'thick' description of the social phenomenon to the development of an explanatory theoretical model, grounded in the data.

\section{Participants}

It is recognised that people with ID are especially vulnerable to being victims of sexual abuse (Brown \& Stein, 1998), but the problem is a very hidden one. It was anticipated therefore that it would be difficult to recruit participants, so purposive sampling was used. Initially, interview participants were contacted through a clinical psychologist who often acted as an expert witness. As the aim of recruiting a pool of 20 interview partners could not be reached through this procedure, the recruiting process was extended to contacting participants through a Day Centre in the UK, in the Trust where the psychologist worked, and an Independent Sexual Violence Advisor (ISVA) from a UK charity. The Day Centre was identified as working with potential study participants through personal knowledge of the expert witness, but in the end participants declined and could not be recruited through this route. The charity was contacted as an organisation known to work with people with intellectual disabilities who have been victims of sexual abuse, their families and professionals supporting them.

Finally, after contacting 37 potential participants with ID, all of whom had been alleged victims of abuse and all of whom had capacity to consent, only 4 people with ID agreed to talk to the author about their experiences; in addition the 4 carers/supporters also agreed to participate. Some of the latter had attended court in several cases and one was interviewed regarding 3 different cases. None 
of the cases had resulted in a conviction, though this is by no means unusual for cases involving alleged victims with ID. Of the 8 interview participants, 7 were white British, one person was African and all of them were female (see Tables 2 \& 3).

\section{Measures}

Interview questions were constructed with the help of three experts: one expert witness (psychologist), an experienced researcher in the field of intellectual disabilities and sexuality, and an experienced qualitative researcher. Two slightly different sets of interview questions were constructed: one for the carers and one for the people with ID. Differences between the two consisted of simplified wording and adding of pictures and symbols for people with ID in order to fit their needs. The interviews consisted of a brief set of demographic questions (age, gender, diagnosis, offence alleged, outcome in court), followed by an initial set of 6 questions accompanied by several possible prompts (see Table 1). If participants with ID did not want to talk to the author alone, their carer was allowed to be present during their interview. Prompts from carers in order to facilitate recall of the events were accepted, as long as the carers' comments did not substitute the victims' responses. The interviews were audio recorded with participants' permission and transcribed.

\section{(Table 1 about here)}

\section{Procedure}

Ethical approval was obtained from the Tizard Centre Ethics Committee. 
Consent was obtained from all 8 participants. All interviews were conducted in participants' homes or their work offices and lasted between 30 and 60 minutes. All the interviews were taped and transcribed verbatim. All participants were informed about the purpose and procedure of the project by an initial introduction letter and an information sheet. Only those able to consent for themselves were included and all participants signed consent forms. As soon as data collection started, all data were given a participant code and no participant information was to be found on the raw data. This accounted for the whole period of the project, as well as for any subsequent data analysis, publication or conference presentation.

(Tables 2 \& 3 about here)

\section{$\underline{\text { Analysis }}$}

In keeping with the Grounded Theory approach (Glaser \& Strauss, 1967; Strauss \& Corbin, 1998), data collection and data analysis were conducted simultaneously. Transcripts were initially rigorously read multiple times by the two first authors who independently coded and categorised the data. Patterns of categories were subjected to a process of 'constant comparison' between the codes and the categories, in order to adjust and refine them using further data gathering. In this way participants' intentions, meanings, actions and situations were studied, whilst the researcher stayed close to the data, so concentrating and reflecting on what participants said, rather than on preconceived hypotheses. Thus accounts from different individuals were compared with each other, data from the same individuals were compared with themselves at different time points, and data were compared with emerging categories, which 
were refined and re-defined. Elongated discussions between the authors comparing categories and sub-themes followed, until saturation and thematic reliability were achieved. This process yielded four overarching themes that moved beyond description to interpretation, and which both first authors agreed on $100 \%$. As a result of this process a theoretical framework was also developed which explained the data.

\section{Results}

Out of 37 sets of information sheets sent out in a variety of ways (see Methods) only 8 people agreed to take part. 4 of them were people with intellectual disabilities, 2 of them were family members acting as their carers, one of them was a service manager interviewed as a carer and one of them was an Independent Sexual Violence Advisor (ISVA) acting as a carer in 3 different cases (see tables 2 and 3 for details). In order to ensure anonymity, all the names used have been changed.

Four superordinate themes emerged from the analysis of the data. These were:
a. Trauma
b. Fluctuating support
c. Mutual (mis)understanding
d. (In)justice

The themes include several categories and subcategories and these are summarised with illustrative examples below and in table 4 . The quotes chosen 
in the table add to the quotes in the text, so the reader is referred to both the text and the table. The data and the resulting themes were used to generate a theoretical model (see Figure 1), as is usual in Grounded Theory

(Figure $1 \&$ Table 4 about here)

\section{a. Trauma}

'Trauma' related to people's emotional, mental and behavioural reactions to both the events of the incident (sexual assault) and the court case. It described the impact of these events on the victims', carers' and relatives' emotional and mental health. Manifestations of reactions to the incident include emotional and mental ill-health, like symptoms of depression or being at risk of committing suicide, or complete withdrawal.

'[...] and she was just erm... suicidal. She was just going off the wall, completely.'(Angela, Interview 8)

It seemed that not only the incident, but also the court case could be experienced as a traumatic event, so that shock and disbelief, after coming out of the courtroom, were expressed in participants' stories.

'I was traumatised! Absolutely traumatised. I can honestly say it's probably the worst experience I've had in my life. It was awful.'(Camilla, Interview 1)

Cross-examination, and some lawyer's behaviour in court, were perceived as a second act of violence against them. This was also expressed by one of the victims saying that she would not want anyone else to have to go through the same experience as she did.

'It's almost like she's been violated twice, do you know what I mean, by the abuser 
and then by the court (Conny, Interview 4).'

The difficulties people experienced with questioning in court were associated with both the types of questions (which were often leading questions, suggestions or even accusations) and the style of questioning (which - especially in cross-examination - was perceived as harsh, cold, aggressive and manipulative). 'And then the defence asked 'Why did you let him in? Why did you let him into your bedroom?' You know... 'I put it to you that you enjoy having sex with him.' (Angela, Interview 7)

The way victims and carers felt about the judges and the lawyers depended a lot on their understanding of ID and how they behaved towards them. A judge was perceived as helpful and supportive if he understood the needs of the victim in offering breaks, giving more time to answer and stopping inappropriate questioning by a lawyer. Consequently, the judges and the lawyers were perceived as rude, aggressive and inappropriate if they clearly showed no understanding of ID.

'I didn't like the judges either (Paula).

'What was wrong with the judge? (Interviewer).

'Rude' (Paula).

'Yeah he was very rude to you. He brought... the judge would come up to the room where we waited and he brought the defendants with him as well. Erm... the judge asked ... a question, and you could obviously see that P. was very nervous and only gave a one-syllable- answer. And he was quite aggressive in saying 'well I hope 
you're not gonna be like that when you're being interviewed' (Conny).' (Interview 4)

'Trauma' also included the long-term impact that the incident and the court case had on people. The need for psychological support was often expressed, and in some cases there seemed to have been some permanent changes in the person's perspective on life, including a loss of trust towards other people, a feeling that people were generally bad, and/or that all men were bad.

'[...]oh all these men in my life... I need more support on that side, to deal with all the men. And it hurts. It's really hurting me.'(Sarah, Interview 9)

The fear of seeing the perpetrator referred to feelings generated both outside court (before and after the court case), and inside the court itself. Protective screens and/or the use of a video link went some way to preventing this in court and this was considered helpful, but in one case this was not enough as the fear of the perpetrator was too overwhelming. 'But she was very conscious of the fact that he was looking at her. Although she couldn't see him she was very conscious of the fact that he was there. And he was in the same building as her and she was terrified.' (Camilla, Interview 1)

\section{b. Fluctuating Support}

'Fluctuating Support' described the need for appropriate support for the victims and their carers in order to cope with the trauma they were experiencing and with the court case, and the consequences of not receiving this support. 
Support that was beneficial to the victims stemmed from several sources. The first situation in which victims need support is when they get in touch with the police. Generally the police were considered as helpful and supportive, especially before the court case.

'The officer...the policewoman I spoke to... When I first spoke to them I told them that he'd raped me. So they took me inside so no one else don't hear it. There was this policewoman called K.. I keep in contact with her, she's a nice lady. Without the police I wouldn't know where to get to.' (Sarah, Interview 9)

The next step in supporting people entailed the preparation for court and explanations about further police and court procedures. Good preparation for court included knowledge about the special measures that could be used, and what advantages or disadvantages the different measures would have for them.

'She was talking about - at one point- doing the video-link... [...] it's so impersonal, although you're in a little room doing it the whole court can see you. There are these big flat plasma screens all around the court, so everybody can see you. Whereas if you're behind screens for special measures, the only people who can see you are the defence, the prosecution, the jury and the judge.' (Angela, Interview 7)

Both the need for psychological support and the need for an advocate before and during the court case were expressed by victims and carers. This is due to the lack of experience people have with court, and their barristers, even though they were their 'advocates' seem to be unable to fulfil this role. Family members and 
carers also found it difficult to advocate for the people they supported due to their unfamiliarity with court.

'She really needed the psychological support. She couldn't have gone through the court case without it. [...]The counselling is helping me. It's good that I'm in counselling.' (Camilla, Interview 1)

'For other people... other women... get somebody, some... and advocate, to help them to go to court. Even if it's him to speak up instead of your own self. This is, I have my first advocate now. In the past I didn't have one. '(Sarah, Interview 9)

The interviews with the Independent Sexual Violence Advisor (ISVA), who was a supporter in several cases, showed that her experience with the police and the Criminal Justice System was a big advantage when it came to fighting for the rights of the victim.

'But I think in all rape cases, whether you have a learning disability or not, I think it's really important that erm... you're allowed to come in through the back entrance. In most courts this happens automatically, so that you're not likely to bump into the perpetrator's family or friends. We had to remind the witness service that we are allowed to come in through the car park.'(Angela, Interview 8)

The third crucial source of support for both the victims and their carers was their social network. The importance of this source of support becomes even clearer in those cases in which it was lacking or where the support was inappropriate. 
...but the thing is you had to rise up to it and deal with it and I'm on my own, I'm not married or haven't got a partner.[...] Yes I needed someone to talk to. I didn't actually have anyone.I kind of felt like I wanted someone here with me, but there was no one, so...' (Camilla, Interview 1)

In several interviews people complain about a lack of support after the end of the court case.

We never had any follow-up visits, I even asked the psychologist to come and see her because I was concerned. She started self-harming afterwards, pulling her hair out and scratching herself. Because it stopped very suddenly, she gave her evidence and that was it, they didn't see her again. It wasn't fair'. (Whitney, Interview 2)

But in some situations people felt let down by social services already before the court case, as they are not getting enough support, or none at all, even though they had to cope with the trauma of being a rape victim. 'I only had 2 hours support, that was all, just one day, once a week. That was not enough. Until they put it up to seven hours, and then they reduced it to five later. [...] No it's not enough! I need it 24/7. That's what I need. Because I'm worried about strangers that I see on the street.' (Sarah, Interview 9)

\section{c. Mutual (mis) understanding}

Mutual (mis)understanding refers to understanding of intellectual disabilities 
(or the lack thereof) as well as the lack of understanding of the Criminal Justice System by the people interviewed. Understanding or lack of understanding of intellectual disabilities denotes the difference between those people who know, have lived or worked with someone with an ID and therefore understand their behaviour, and those who lack these experiences.

'People in the jury were judging a circumstance where they didn't necessarily understand where S. was coming from because of her disability I think. There are certain sort of patterns they don't follow. But someone from outside must think it's really weird.'(Camilla, Interview 1)

The other way of looking at 'understanding of ID' was the general lack of understanding of the police, the court staff, judges, and lawyers and how this manifested itself. Their inappropriate behaviour towards someone with an ID could be perceived by carers and victims as mocking the person with ID, judging them because of it, or even as aggression.

'I actually thought it was totally out of order. The way they spoke and the defendants...It felt like... because I spoke to them about P's response time, because I didn't want the judge to ask P. something and then he was waiting for ages, thinking that she's ignoring him. And when I expressed about the...you know the... that P. needs to process the information there was two ladies and they just giggled [...]And I could see P's mood changing, you know, especially when he said 'well I hope you're not gonna give yes and no answers when you're being interviewed'.(Conny, Interview 5) 
Professionals that lacked understanding are also perceived as incompetent: when an intermediary got downgraded to a chaperone (i.e. someone simply accompanying the witness), it was considered to be due to the inability of the prosecution barrister to defend the victims' need for it.

'Erm... the defence counsel went into her history of breakdowns and things. And then suddenly let the court know that the defendant has an IQ of 52. Which is a complete and utter lie. The prosecuting counsel did not stop the case and say I want to make enquiries about this', because he knew nothing about it.'(Angela, Interview 6)

In contrast, some judges were perceived very positively, and as understanding of ID when he or she offered the victim to go through the trial in their own time.

'And then the judge says 'In your own time T., if you want a break, just let me know, and we'll have a break.' (Tanya, Interview 10)

On the other hand, victims and carers lacked understanding of police procedures, the court process, the language used in court and they expressed the need for more and better information.

'They speak in jargon and they tend to use long words. They use some words, don't they. S. understands the majority of things, but people tend to talk to her at a level she can understand.' (Camilla, Interview 1) 
The information people got about court procedures and the language used was considered as not very helpful.

'And it didn't help P. at all really. Watching the video. We watched it about 3 times, and she still didn't get it at the end of it when I was asking her questions about it. It was a video about when you go to court, explaining what happens in court, and actually, nothing happened like, it didn't happen like that at all, you know, so...in P's eyes it was giving her false information, because it didn't happen how it was said on the video. '(Conny, Interview 4)

\section{d. (In)justice}

The category '(In)justice' contains two aspects that opposed each other. On one hand, people saw the court case as an opportunity to deliver justice, as a chance to fight for themselves or their clients and have the perpetrator punished for what he allegedly did. On the other hand, several factors during and after the court case contributed to a feeling of 'injustice', all linked to a no-convictionoutcome. The feeling of having an opportunity to fight for justice came with high hopes and was the motivation to go ahead with the court case in the first place. 'I felt like it was, for her, a chance to have her say and to defend herself because at the time she couldn't defend herself.[...] She wanted him to go to court because she didn't want him to do it to someone else.'(Camilla, Interview 1)

Unfortunately the factors that contributed to 'injustice' were stressed more 
often. A 'not-guilty' outcome of the case was perceived as injustice, as the alleged victims and carers felt they 'knew what really happened' and that the alleged perpetrator 'was guilty'. This feeling of injustice is accompanied by frustration, anger and disbelief.

'I mean, if he'd gone to prison then I would have felt like if justice has been done and it hasn't... and you've got no sort of way of...feeling like justice.' (Conny, Interview 5)

Cross-examination is also perceived as unfair and disempowering: due to the style of questioning, it was considered as disabling people from fighting for themselves or the person they supported.

'I didn't feel like I had my say, I felt like I was led (...) I felt like it came down to how clever the lawyers were, the barristers were, and not to the actual facts.' (Camilla, Interview 1)

Finally, the fact that an intermediary could be downgraded to a chaperone who was not allowed to interpret for the victim in court, or to interrupt the defence lawyer if cross-examination was inappropriate, was perceived as injustice. 'And this is a woman with a learning disability who hasn't got an intermediary, she's only got a chaperone standing there now. And the intermediary is not allowed to stop or say anything about the way of the questioning. And the intermediary said it was absolutely appalling.'(Angela, Interview 7)

Another part of 'Injustice' described general difficulties with the Criminal Justice System that could be more of a disadvantage to people with ID than for the 
general population, like long waiting periods, but also inconsistencies in court organisation, financial issues and failure of the system to provide the services needed by vulnerable adults.

'When you say it's gonna happen next year in February, that doesn't mean anything to her. So we started doing timelines, hoping for her that she could understand that way, but... and then they'd change it and she'd be frustrated and rip it up. You know, so it was quite a hard time for her. And frustrating for me, because it took so long. ' (Conny, Interview 4)

As 'waiting' was due both to organisation of the court and quite often to legal arguments, the right support during that time was important and could make those situations easier to cope with.

'[...] it was about 8 months waiting period. So what I do with my clients is trying to get them involved in other things. (Angela, Interview 6)

'Inconsistencies' in court organisation referred to organisation leading up to the trial, but also to organisation on the day in court by the court staff, and this could lead to situations for which the alleged victims were not prepared, and could hinder the provision of the right support for the victims.

'Then we discovered that the perpetrator has been released on bail, he was no longer on remand. Nobody bothers to tell us. [...] the CPS just seemed to keep really quiet about it. So there was a breakdown of communications. I then found out that the intermediary hadn't been warned for court.' (Angela, Interview 8) 


\section{Discussion}

\section{Theoretical model}

The findings of this study describe the experiences of 4 people with ID and 4 carers/supporters, with the criminal justice system. The sample was small and it would be unwise to generalise results, as this was exploratory research.

The core of the theoretical framework developed from the themes (see Figure 1) was a circle of negative experiences associated with the traumatic experiences of the rape and the court case. The incident was the primary source of trauma and the court case was a secondary source of trauma, and it is proposed that both these experiences resulted in the formation of the intertwined feelings of anxiety, anger and injustice, and mutual misunderstanding between the alleged victims and the officials in the Criminal Justice System. Anxiety and anger were associated with seeing the perpetrator outside on the street and/or in court, and this related back to the trauma of the incident. On the other hand, anxiety was also highly associated with the court case: the fear of the unknown was a feeling that could play an important role in understanding or misunderstanding of the CJS and the people and the processes involved in it. On the other side of the coin, was the lack of understanding of ID by the people involved in the CJS, which led to extensive feelings of disadvantage and injustice for the alleged victims. People saw the process of going to court as a way of getting justice and the fact that the alleged perpetrators did not get convicted (in this sample) produced for them additional negative feelings of anxiety and anger, this time due partly to the 
possibility of seeing the perpetrator outside, after the court case, also leading back to the trauma of the incident. Furthermore, the likelihood of getting a conviction was strongly reduced by the lack of understanding of ID by the CJS: the police sometimes failed to collect and hand over important evidence (though in some cases the police had clearly done a very good job and were praised by participants); the lawyers sometimes were perceived as aggressive and did not defend the need for an intermediary; and/or the judges rarely intervened in line with the needs of the people with ID. These problems sometimes led to the dropping of the case before it went to court or a cross- examination that was experienced as a second (albeit lesser) act of violence against the victim.

Nevertheless, barristers are taught to cross-examine in a pressing, persistent and harrying style. It would have been difficult for them to do otherwise given the number of years many of them had been practising, before the cases in question. Moreover, they may have found it hard to understand why the person with ID should be treated any differently from any other witnesses, since they knew so little about ID, and judges may have been worried that a re-trial might be ordered if they were seen as being biased in favour of the witnesses.

Fluctuating support was an aspect of this framework that had the potential to aggravate the whole experience for the alleged victims and carers. As good support aims to reassure and empower victims, increasing their independence, advocating for them and preparing them for court, it plays a very important part in helping people with ID cope with feelings of anxiety, anger and injustice, and also in helping them to understand the CJS, and thus be more reliable witnesses. 
This raises several issues: if the support is not appropriate, the spiral of negative experiences followed by negative feelings, leading to more negative experiences, cannot be interrupted. Also if victims do not get the appropriate support in court, the disadvantages they have in the CJS that are due to the ID - like delayed processing speed, acquiescence and suggestibility - are added to by further disadvantages caused by the lack of knowledge about ID of the people involved in the CJS.

The findings of this project support previous research that has been done with child victims of sexual abuse and their experiences in court. The three main difficulties that were found were prolonged waiting periods, fear of seeing the accused in court and the cross-examination process, all of which were feeding in to the trauma of the court experience. The children also exhibited similar emotional and mental health problems as did people with ID during the wait for trial: thoughts about suicide, self-injury, depression and anxiety (Eastwood \& Patton, 2002).

\section{Implications}

Resulting from the theoretical framework presented (Figure 1), a strategy for intervening in this negative spiral was developed (Figure 2). The proposal is for changes in the CJS, but also for the development of better and more specialised support systems for people who are victims of sexual abuse and who go through a court process.

(Figure 2 about here) 
The core idea of this proposal for intervention is that if people get the right support before, during and after the trial, and the people involved in the CJS get the right training about the rights and needs of people with ID, the experience of the court case as a secondary trauma could be avoided or at least reduced. Support before the court case ought to include psychological support for the victims and their carers or families, support by social services, and support by an advocate who is familiar with ID and court processes, to balance out the disadvantages people have in court due to their ID.

A protocol between the police and the CPS states that in every rape case an ISVA should be contacted by the police (CPS, 2013). This is clearly not always the case and people stated that they felt unprepared for the court process even though they were given material to read and watch. This material tended to be unsuitable for people with ID, even though it was directed at 'vulnerable witnesses'. These findings of lack of preparation for court support the findings of studies conducted with child complainants of sexual abuse who lack knowledge of legal procedures leading to negative psychological consequences before, during and after trial (Goodman et al., 1998; Sas et al., 1996).

Empowerment and promotion of independence are necessary to reduce shame and stigma and to give the people the impression that even though they have a difficult experience ahead of them, it will be worthwhile, because the idea that it will not be worth going to court seems to be widespread for vulnerable witnesses. Nevertheless, it is also necessary to make sure alleged victims are 
aware that perpetrators may not be convicted in court: amongst our participants not one case had resulted in a conviction.

During the trial, the need for an advocate was expressed by several participants of this project as lawyers tended to be unable to fulfil this role properly. It can be argued that if the prosecution lawyers are not informed about ID, they are unable to prosecute the case in a way that would deliver justice. As the Youth Justice and Criminal Evidence Act 1999 states, every person with ID has a right to an intermediary in court (Cooke \& Davies, 2001). But in three of the cases presented, intermediaries were downgraded to chaperones who were not allowed to help their clients with understanding, due to the lack of knowledge about ID of prosecution attorneys and their inability to defend alleged victims' rights to an intermediary. As research shows that people with ID generally have more difficulties following court proceedings and are more likely to acquiesce, to be compliant and suggestible (Clare \& Gudjonsson, 1993), it is important to have intermediaries present right at the beginning of the first police interview through to the end of the court case. So prosecuting attorneys need to have a basic knowledge about ID in order to be able to defend the use of an intermediary in court.

Training is also needed for the judges, the jury and all the other court staff. Judges are allowed to intervene in cross-examination if they consider it is inappropriate, or to call for breaks if they think the alleged victim needs them (Pattenden, 1990). However, research suggests that judges generally do not differentiate between witnesses with ID and witnesses of the general population 
in terms of their style and interventions in cross-examination (Kebbell et al, 2004; O’Kelly et al., 2003).

Findings from this study show that court processes, court environments and witness services are not witness-friendly, and this is supported by findings from child complainants studies (Eastwood \& Patton, 2002). In a report from the Commons' Home Affairs Select Committee that was published in June 2013, several recommendations were made in relation to: support services for child and vulnerable witnesses; training for legal participants; and the introduction of specialist courts for sexual offences (Home Affairs Committee, 2013). These recommendations included 'that forces identify support services to provide care to victims and their extended families for the duration of their criminal justice journey and beyond' and they recommended 'that all victims of child sexual exploitation be offered the services of an Independent Sexual Violence Advisor prior to their Achieving Best Evidence interview' (Home Affairs Committee, 2013). They also noted that these support services should be available for all vulnerable witnesses, including people with ID and mental health problems. The suggestion of introducing specialist courts which would be set up after the model of domestic violence courts, was rejected by the Lord Chief Justice, Lord Judge. However, the recommendation of introducing specialist judges 'qualified to conduct lengthy child sex abuse cases ....... to protect vulnerable witnesses from excessive cross-examination in court' was approved (Guardian Newspapers, 2013). The Bar Standards Board welcomed this decision and announced the introduction of the Quality Assurance Scheme for Advocates, a formal system to ensure a systematic means of assessing, among other things, 
whether barristers are able to deal with cases involving vulnerable witnesses in a competent and appropriate manner (Bar Standards Board, 2013).

\section{Limitations}

As an exploratory qualitative study, the numbers of intended participants were kept deliberately low. But being such a sensitive topic, recruiting participants was very difficult. This certainly had an impact on the results of the study, as only female participants agreed to take part and only court cases without a conviction could be included, so talking to male participants or to people about a court case with a conviction might have led to a different account. In some interviews, the court case happened quite a while ago, which may have made it difficult for people to remember everything. In two interviews with victims the carers were present, partly because victims did not want to be interviewed alone and partly because carers helped by reminding the victims of the context. Sometimes prompts were used, and it was difficult for the researcher to always differentiate between neutral prompts and leading prompts. In order to offer the participants several ways of asking a question, sometimes the questions might have led them more than was intended by the author. Another potential difficulty with having the carers present during the interview was that carers could answer for the alleged victims and cover up the victim's opinion. In one of the two interviews with the carers present, this problem was dealt with by directing the questions to the victim and the carer offering prompts to the victim, with the victim answering herself. In the second interview this problem could unfortunately not be overcome. Therefore no quotes were used in the analysis from that interview. 


\section{Acknowledgements.}

We are extremely grateful to all the participants, with and without ID, who took part in this study. 


\section{References}

Anderson, C. (1982) Teaching People with Mental Retardation about Sexual Abuse Prevention. Santa Cruz, CA: Network Publications

Bar Standards Board (2013) https://www.barstandardsboard.org.uk/mediacentre/latest-news/bsb-responds-to-lord-chief-justice $\% \mathrm{E} 2 \% 80 \% 99$ s-plans-forspecialist-judges 22.08.2013

Bottoms, B. \& Goodman, G. (1994) Perceptions of children's credibility in sexual assault cases. Journal of Applied Social Psychology, 24, 702-732.

Brown, H., Stein, J. and Turk, V. (1995) The sexual abuse of adults with learning disabilities: Report of a second two-year incidence survey. Mental Handicap Research,8, 1, 3-24.

Charmaz, K. (2008) Grounded Theory. In: Smith, J. (ed.). Qualitative Psychology. A Practical Guide to Research Methods. London: Sage Publications Ltd.

Clare, I. \& Gudjonsson, G. (1993) Interrogative suggestibility, confabulation and acquiescence in people with mild learning disabilities (mental handicap): Implications for reliability during police interview. British Journal of Clinical Psychology, 32, 295-301.

Cooke, P. \& Davies, G. (2001) Achieving best evidence from witnesses with learning disabilities: new guidance. British Journal of Learning Disabilities, 29, 84-87.

Crown Prosecution Service (2013) http://www.cps.gov.uk/publications/agencies/rape_protocol_annex_a.html 19.07.2013

Douglas, L. \& Cuskelly, M. (2012) A focus group study of police officers' recognition of individuals with intellectual disability. Psychiatry, Psychology and Law, 19, 1, 35-44.

Eastwood, C., Patton, W. (2002) The experiences of child complainants of sexual abuse in the criminal justice system.

http://www.ncjrs.gov/App/publications/abstract.aspx?ID=196600 20/08/13

Ericson, K. \& Isaacs, B. (2003) Eyewitness identification accuracy: A comparison of adults with and those without intellectual disabilities. Mental Retardation, 41, 3, 161-173. 
Ericson, K. \& Perlman, N. (2001) Knowledge of legal terminology and court proceedings in adults with developmental disabilities. Law and Human Behaviour, 25, 5, 529-545.

Everington, C. \& Fulero, S. (1999) Competence to confess: Measuring understanding and suggestibility of defendants with mental retardation. Mental Retardation, 37, 3, 212-220.

Finkelhor, D. (1994) The international epidemiology of child sexual abuse. Child Abuse and Neglect.18, 409-17.

Gendle, K. \& Woodhams, J. (2005) Suspects who have a learning disability: police perceptions toward the client group and their knowledge about learning disabilities. Journal of Intellectual Disabilities, 9, 70-81.

Glaser, B. \& Strauss, A. (1967).The Discovery of Grounded Theory. Chicago: Aldine. Goodman, G., Tobey, A., Batterman-Faunce, J., Orcutt, H., Thomas, S., Shapiro, C. \& Sachsenmaier, T. (1998) Face-to-face confrontation: effects of closed-circuit technology on children's eyewitness testimony and juror's decisions. Law and Human Behavior, 22, 165-203.

Green, G. (2001) Vulnerability of witnesses with learning disabilities: preparing to give evidence against a perpetrator of sexual abuse. British Journal of Learning Disabilities, 29, 103-109.

Guardian Newspapers Limited (2013) http://www.lexisnexis.com.chain.kent.ac.uk/uk/nexis/results/docview/docvie w.do?docLinkInd=true\&risb=21_T18005723118\&format=GNBFI\&sort=BOOLEA $\mathrm{N} \&$ startDocNo=26\&resultsUrlKey=29_T18005723122\&cisb=22_T18005723121 \&treeMax=true\&treeWidth=0\&csi=138620\&docNo=48 22.08.2013

Gudjonsson, G., Murphy, G. \& Clare, I. (2000) Assessing the capacity of people with intellectual disabilities to be witnesses in court. Psychological Medicine, 30, 307-314.

Hamlyn, B., Phelps, A., Turtle, J. \& Sattar, G. (2004) Are Special Measures Working? Evidence from Surveys of Vulnerable and Intimated Witnesses. London: Home Office Research Report, Study 283.

Hayes, S. (2007) Missing out: offenders with learning disabilities and the criminal justice system. British Journal of Learning Disabilities, 35, 146-153.

Hellenbach, M. (2011) Learning disabilities and criminal justice: custody sergeants' perceptions of alleged offenders with learning disabilities. British Journal of Learning Disabilities, 40, 15-22. 
Herr, S. (1999) Capacity for consent in legal representation. In: Dinerstein, R., Herr, S. \& O’Sullivan, J. (eds.) A Guide to Consent. Washington, DC: American Association on Mental Retardation.

Home Affairs Committee (2013)

http://www.publications.parliament.uk/pa/cm201314/cmselect/cmhaff/68/6 8i.pdf 22.08.2013

Home Office (1998) Speaking Up for Justice. Report of the Interdepartmental Working Group on the Treatment of Vulnerable or Intimidated Witnesses in the Criminal Justice System. London: Home Office

Home Office (2000) Setting the Boundaries: Reforming the Law on Sex Offences, Vol. 1. London: Home Office Communication Directorate

Home Office (2002) Achieving Best Evidence in Criminal Proceedings: Guidance for Vulnerable or Intimidated Witnesses, Including Children (Report of the Memorandum Project Steering Group). London: Home Office Communication Directorate.

Kebbel, M., Hatton, C. \& Johnson, S. (2004) Witnesses with intellectual disabilities in court: What questions are asked and what influence do they have? Legal and Criminological Psychology, 9, 23-35.

Lyall, I., Holland, A. \& Collins, S. (1995) Offending by adults with learning disabilities and the attitudes of staff to offending behaviour: Implications for service development. Journal of Intellectual Disability Research, 39, 501-508.

McBrien, J. \& Murphy, G. (2006) Police and carers' views on reporting alleged offences by people with intellectual disabilities. Psychology, Crime and Law, 12, 2, 127-144.

McCarthy, M. \& Thompson, D. (1997) A prevalence study of sexual abuse of adults with intellectual disabilities referred for sex education. Journal of Applied Research in Intellectual Disabilities, 10,2, Special Issue on Sexuality. pp. 105-124.

Milne, R., Clare I. \& Bull, R. (1999) Using the cognitive interview with adults with mild learning disabilities. Psychology, Crime and Law, 5, 81-101.

Murphy, G. (2007) Intellectual disability, sexual abuse, and sexual offending. In Carr, A., O'Reilly, G., Walsh, P. \& McEvoy, J. (Eds.), The handbook of intellectual disability and clinical psychology practice (pp. 831-866). New York: Routledge/Taylor \& Francis Group.

Murphy, G. \& Clare, I. (2006) The effect of learning disabilities on witness testimony. In: Heaton-Armstrong, A., Shepherd, E., Gudjonsson, G. \& Wolchover, 
D. (Eds.) Witness Testimony: Psychological, Investigative and Evidential Perspectives (pp. 43-60). New York: Oxford University Press.

Murphy, G., O'Callaghan, A. \& Clare, I. (2007) The impact of alleged abuse on behaviour in adults with severe intellectual disabilities. Journal of Intellectual Disability Research, 51, 741-749.

Murphy, G. \& O'Callaghan, A. (2004) Capacity of adults with intellectual disabilities to consent to sexual relationships. Psychological Medicine, 34, 13471357.

O’Day, B. (1983) Preventing Sexual Abuse of Persons with Disabilities: A Curriculum for Hearing Impaired, Physically Disabled, Blind and Mentally Retarded Students. Santa Cruz, CA: Network Publications

O'Kelly, C., Kebbell, M., Hatton, C. \& Johnson, S. (2003) Judicial intervention in court cases involving witnesses with and without learning disabilities. Legal and Criminological Psychology, 8, 229-240.

Pattenden, R. (1990). Judicial Discretion and Criminal Litigation. Oxford: Clarenden Press

Perlman, N., Ericson, K., Esses, V.\& Isaacs, B. (1994) The developmentally handicapped witness. Law and Human Behavior, 18, 171-187.

Sanders, A., Creaton, J., Bird, S. \& Weber, L. (1997) Victims with learning disabilities negotiating the criminal justice system. University of Oxford, Centre for Criminological Research, Occasional Paper No. 17.

Sas, L., Wolfe, D. \& Gowdey, K. (1996) Children and the courts of Canada. In: Bottoms, B., Goodman, G. (eds.) International Perspectives on Child Abuse and Children's Testimony. Newbury Park, CA: Sage.

Saywitz, K. \& Nathanson, R. (1993) Children's testimony and their perceptions of stress in and out of the courtroom. Child Abuse and Neglect, 17, 613-622.

Smith, J. \& Osborn, M. (2003) Interpretative Phenomenological Analysis. In: Smith, J. (ed): Qualitative Psychology. A Practical Guide to Research Methods. London: Sage Publications Ltd.

Stobbs, G. \& Kebbell, M. (2003) Jurors' perceptions of witnesses with intellectual disabilities and the influence of expert evidence. Journal of Applied Research in Intellectual Disabilities, 16, 107-114. 
Strauss, A. \& Corbin, J. (1998) Basics of Qualitative Research. Techniques and Procedures for Developing Grounded Theory. Thousand Oaks: Sage Publications Ltd.

Tharinger, D., Horton, C. \& Millea, S. (1990) Sexual abuse and exploitation of children and adults with mental retardation and other handicaps. Child Abuse and Neglect, 14, 301-312.

Turk, V. \& Brown, H. (1993) The sexual abuse of adults with learning disabilities: Results of a two-year incidence survey. Mental Handicap Research, 6, 3, 193-216.

Van Nijnatten, C. \& Heestermans, M. (2010) Interviewing victims of sexual abuse with an intellectual disability: a Dutch single case study. Journal of Social Work Practice, 24, 391-407.

Voice UK (1998) Competent to tell the truth. Derby: Voice UK 


\section{Table 1}

Questions used in the interview (excluding demographic questions)

\begin{tabular}{|l|l|}
\hline Question & $\begin{array}{l}\text { The first statements are given below. The questions which follow } \\
\text { were used as prompts. }\end{array}$ \\
\hline 1. & $\begin{array}{l}\text { First we are going to talk about the time just after the crime was } \\
\text { committed. } \\
\text { Who did you tell first? Do you remember what you said? Do you } \\
\text { remember what they said? Do you remember what they did? }\end{array}$ \\
\hline 2. & $\begin{array}{l}\text { Now we are going to talk about what happened when you talked } \\
\text { to the police. } \\
\text { How did they treat you? What did they say to you? What did they } \\
\text { do? What did you think of the police? How do you feel about } \\
\text { them? }\end{array}$ \\
\hline 5. & $\begin{array}{l}\text { Now we are going to talk about what happened before you went } \\
\text { to court. } \\
\text { How did you feel? Did you get any help? How did they help you? } \\
\text { What did they say? What did they do? }\end{array}$ \\
\hline ple? How did you feel? How did people treat you? \\
What
\end{tabular}


Table 2. Participant's details (people with ID)

\begin{tabular}{|l|l|l|l|l|}
\hline Name & Age & Diagnosis & Offence & Outcome \\
\hline Kerry (ID) & 27 & $\begin{array}{l}\text { Intellectual } \\
\text { disability caused by } \\
\text { stroke }\end{array}$ & Alleged rape & Not guilty \\
\hline Paula (ID) & 41 & $\begin{array}{l}\text { Intellectual } \\
\text { disability }\end{array}$ & $\begin{array}{l}\text { Indecent } \\
\text { assault in 3 } \\
\text { cases }\end{array}$ & Not guilty \\
\hline Sarah (ID) & 50 & $\begin{array}{l}\text { Intellectual } \\
\text { disability and } \\
\text { mental health } \\
\text { problems }\end{array}$ & $\begin{array}{l}\text { Rape and } \\
\text { robbery }\end{array}$ & $\begin{array}{l}\text { Hung } \\
\text { jury/Not } \\
\text { guilty }\end{array}$ \\
\hline Tanya (ID) & 66 & $\begin{array}{l}\text { Intellectual } \\
\text { disability }\end{array}$ & Rape & Not guilty \\
\hline
\end{tabular}


Table 3. Participants details (carers)

\begin{tabular}{|l|l|l|l|l|}
\hline Name & Age & $\begin{array}{l}\text { Relationship to } \\
\text { the person they } \\
\text { support }\end{array}$ & $\begin{array}{l}\text { Offense } \\
\text { committed against } \\
\text { the person they } \\
\text { support }\end{array}$ & Outcome \\
\hline Camilla & 53 & Mother & Rape & Not guilty \\
\hline Whitney & 47 & Aunt & Alleged Rape & Not guilty \\
\hline Conny & 57 & Manager & $\begin{array}{l}\text { Indecent Assault } \\
\text { in 3 cases }\end{array}$ & Case dropped \\
\hline Angela & 67 & ISVA in 3 cases & $\begin{array}{l}\text { Rape in 3 different } \\
\text { cases }\end{array}$ & $\begin{array}{l}\text { Not guilty in 3 } \\
\text { different cases }\end{array}$ \\
\hline
\end{tabular}


Table 4 Themes and sub-themes

\begin{tabular}{|c|c|c|c|}
\hline Themes & Categories & Sub-Categories & Quotes \\
\hline \multirow[t]{3}{*}{ Trauma } & $\begin{array}{l}\text { Impact of } \\
\text { incident and } \\
\text { court case on } \\
\text { emotional and } \\
\text { mental health }\end{array}$ & $\begin{array}{c}\text { Behavioural and } \\
\text { emotional } \\
\text { reactions }\end{array}$ & $\begin{array}{c}\text { 'It's almost like she's been } \\
\text { violated twice, do you know } \\
\text { what I mean, by the abuser } \\
\text { and then by the court } \\
\text { (carer).'I just don't want } \\
\text { them to do that to anyone } \\
\text { else (victim).' }\end{array}$ \\
\hline & $\begin{array}{l}\text { Cross- } \\
\text { examination/ } \\
\text { Questioning } \\
\text { Feelings } \\
\text { associated with } \\
\text { the incident }\end{array}$ & $\begin{array}{l}\text { Type of questions, } \\
\text { style of questioning }\end{array}$ & $\begin{array}{l}\text { 'Because the way they } \\
\text { question you is like... its like } \\
\text { they're trying to catch you } \\
\text { out... they' re trying to force } \\
\text { the conversation their way all } \\
\text { the time (...)' } \\
\text { 'I didn't feel safe. Because } \\
\text { when I was living in ... road, I } \\
\text { didn't want to go back there } \\
\text { in case he comes out and see } \\
\text { me down that street' }\end{array}$ \\
\hline & $\begin{array}{l}\text { Feelings } \\
\text { associated with } \\
\text { the court case }\end{array}$ & $\begin{array}{c}\text { Shame, } \\
\text { embarrassment }\end{array}$ & $\begin{array}{l}\text { 'And I had to tell him. And } \\
\text { then I told my sister. Because } \\
\text { my family had to know. I } \\
\text { didn't want them to know, } \\
\text { but in the end I told them.' } \\
\text { 'But I was petrified, because a } \\
\text { bit nervous. Never spoke in } \\
\text { court before.' }\end{array}$ \\
\hline \multirow[t]{2}{*}{$\begin{array}{l}\text { Fluctuating } \\
\text { support }\end{array}$} & $\begin{array}{l}\text { Beneficial } \\
\text { support }\end{array}$ & $\begin{array}{l}\text { Psychological } \\
\text { support }\end{array}$ & $\begin{array}{l}\text { 'She really needed the } \\
\text { psychological support. She } \\
\text { couldn't have gone through } \\
\text { the court case without it.' }\end{array}$ \\
\hline & & $\begin{array}{l}\text { Advocacy/fighting } \\
\text { for the victim }\end{array}$ & $\begin{array}{l}\text { 'So I mean my job is to make } \\
\text { it as comfortable as possible, } \\
\text { but it's familiarization, to } \\
\text { know, to ask questions, to go } \\
\text { back again, if you've } \\
\text { forgotten anything, you } \\
\text { know. Because there are } \\
\text { people who are paid to look } \\
\text { after you.' }\end{array}$ \\
\hline
\end{tabular}




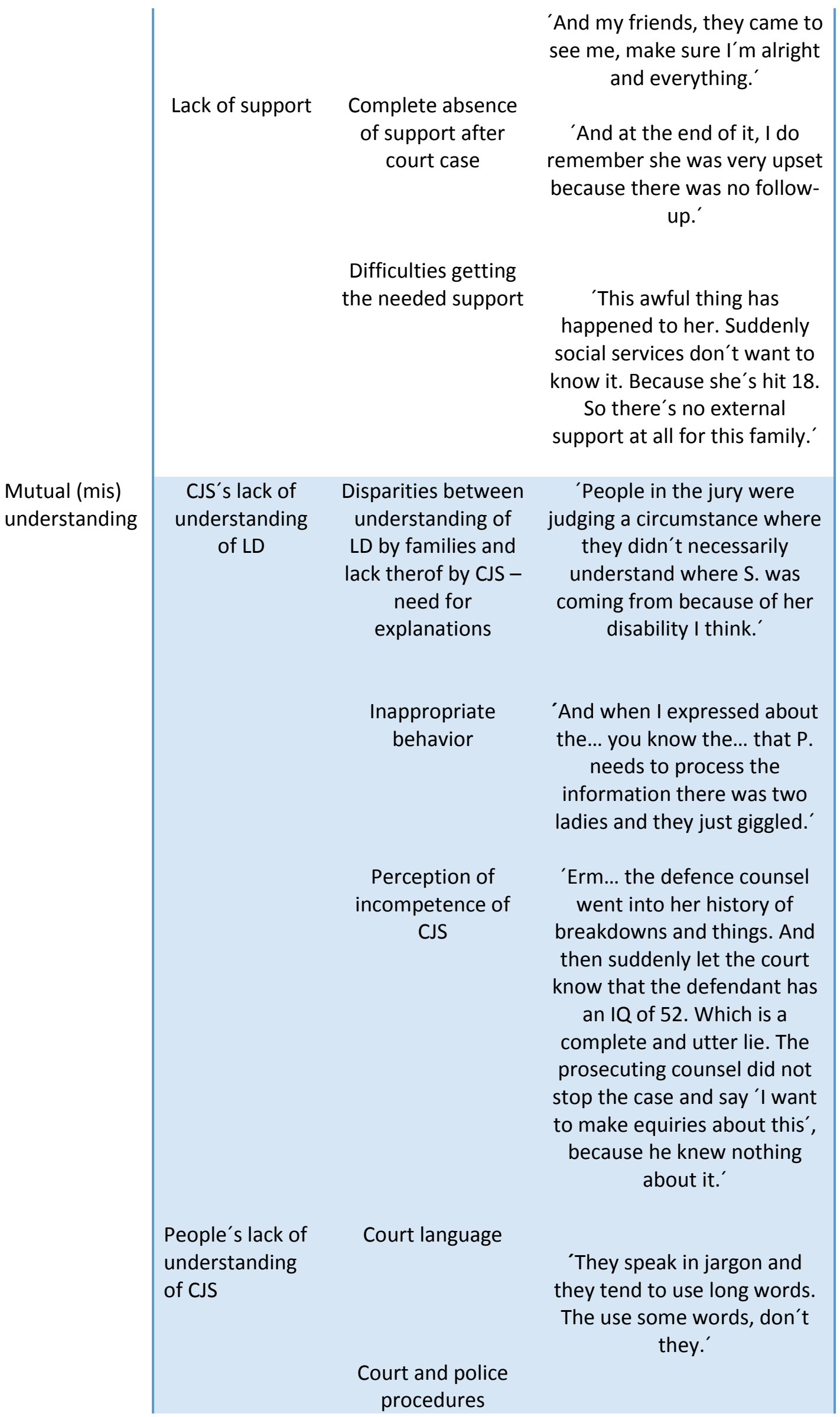




\begin{tabular}{|c|c|c|c|}
\hline & & & $\begin{array}{c}\text { '... the legal system I was } \\
\text { totally unprepared for in that } \\
\text { sense, totally. Because I } \\
\text { thought I've got a reasonable } \\
\text { understanding of how these } \\
\text { things work, but I didn't at } \\
\text { all.' }\end{array}$ \\
\hline \multirow[t]{8}{*}{ (In)justice } & $\begin{array}{c}\text { Court case as an } \\
\text { opportunity to } \\
\text { deliver justice }\end{array}$ & & $\begin{array}{c}\text { 'I felt like it was, for her, a } \\
\text { chance to have her say and to } \\
\text { defend herself because at the } \\
\text { time she couldn't defend } \\
\text { herself.' }\end{array}$ \\
\hline & $\begin{array}{l}\text { Disappointment } \\
\text { of not getting } \\
\text { justice }\end{array}$ & Outcome & $\begin{array}{l}\text { 'It's so frustrating because } \\
\text { she went through so much } \\
\text { and it's... he's just walked } \\
\text { away...' }\end{array}$ \\
\hline & & $\begin{array}{l}\text { Treatment in court } \\
\text { (Disempowerment) }\end{array}$ & $\begin{array}{l}\text { 'I didn't feel like I had my say, } \\
\text { I felt like I was led (...). I felt } \\
\text { like it came down to how } \\
\text { clever the lawyers were, the } \\
\text { barristers were, and not to } \\
\text { the actual facts.' }\end{array}$ \\
\hline & & $\begin{array}{l}\text { Downgrading of } \\
\text { intermediary }\end{array}$ & $\begin{array}{l}\text { 'And this is a woman with a } \\
\text { learning disability who hasn't } \\
\text { got an intermediary, she's } \\
\text { only got a chaperone } \\
\text { standing there now.' }\end{array}$ \\
\hline & & $\begin{array}{l}\text { Incompetence by } \\
\text { the police }\end{array}$ & $\begin{array}{l}\text { '(...) all of a sudden it was } \\
\text { called off and then it would } \\
\text { eventually come to light that } \\
\text { the police hadn't given their } \\
\text { evidence over, so...' }\end{array}$ \\
\hline & $\begin{array}{l}\text { Difficulties with } \\
\text { the CJS }\end{array}$ & $\begin{array}{l}\text { Inconsistencies in } \\
\text { court organization } \\
\text { (Communication) }\end{array}$ & $\begin{array}{l}\text { 'Then we discovered that the } \\
\text { perpetrator has been } \\
\text { released on bail, he was no } \\
\text { longer on remand. Nobody } \\
\text { bothers to tell us.' }\end{array}$ \\
\hline & & Fimancial issues & $\begin{array}{l}\text { 'The intermediary was not } \\
\text { warned for court until about } \\
2 \text { weeks beforehand. That's } \\
\text { after lots and lots of emails } \\
\text { saying 'why hasn't she been } \\
\text { warned for court?' }\end{array}$ \\
\hline & & Waiting & \\
\hline
\end{tabular}


'Yeah they kept changing the court date and that really... I think from the actual first alleged abuse it took about 2 and a half years to get to court. And then they wondered why P. couldn't remember lots of bits and pieces.

\section{Figures}

Figure 1. Results Analysis

Figure 2. Theoretical Framework 